New developments for the site-specific attachment of protein to surfaces

J. A. Camarero

May 18, 2005

Biophysical Reviews and Letters 
This document was prepared as an account of work sponsored by an agency of the United States Government. Neither the United States Government nor the University of California nor any of their employees, makes any warranty, express or implied, or assumes any legal liability or responsibility for the accuracy, completeness, or usefulness of any information, apparatus, product, or process disclosed, or represents that its use would not infringe privately owned rights. Reference herein to any specific commercial product, process, or service by trade name, trademark, manufacturer, or otherwise, does not necessarily constitute or imply its endorsement, recommendation, or favoring by the United States Government or the University of California. The views and opinions of authors expressed herein do not necessarily state or reflect those of the United States Government or the University of California, and shall not be used for advertising or product endorsement purposes. 


\title{
NEW DEVELOPMENTS FOR THE SITE-SPECIFIC ATTACHMENT OF PROTEIN TO SURFACES
}

\author{
JULIO A. CAMARERO
}

Chemical Biology and Nuclear Science Division, Lawrence Livermore National Laboratory, University of California, 7000 East Avenue, L-232,Livermore, California 94550,USA, camarero1@llnl.gov.

\begin{abstract}
Protein immobilization on surfaces is of great importance in numerous applications in biology and biophysics. The key for the success of all these applications relies on the immobilization technique employed to attach the protein to the corresponding surface. Protein immobilization can be based on covalent or noncovalent interaction of the molecule with the surface. Noncovalent interactions include hydrophobic interactions, hydrogen bonding, van der Waals forces, electrostatic forces, or physical adsorption. However, since these interactions are weak, the molecules can get denatured or dislodged, thus causing loss of signal. They also result in random attachment of the protein to the surface. Site-specific covalent attachment of proteins onto surfaces, on the other hand, leads to molecules being arranged in a definite, orderly fashion and uses spacers and linkers to help minimize steric hindrances between the protein surface. This work reviews in detail some of the methods most commonly used as well as the latest developments for the site-specific covalent attachment of protein to solid surfaces.
\end{abstract}

Keywords: Chemoselective ligation, protein chip, protein splicing.

\section{Introduction}

Many experimental approaches in biology and biophysics as well as applications in diagnosis and drug discovery require proteins to be immobilized on solid substrates. ${ }^{1-5}$ In fact the idea of creating protein arrays (i.e. arrays of proteins attached to a solid support) has started to attract increasing attention over the last three years due to the completion of several genomes including the human one. Once a whole genome has been deciphered, the daunting task of determining the function of each protein encoded in the genome still has to be carried out. Protein arrays can be easily used for such analysis in a parallel fashion. ${ }^{6-8}$

Various methods are available for attaching proteins to solid surfaces. Most rely on nonspecific adsorption, ${ }^{9,10}$ or on the reaction of chemical groups within proteins (mainly, amino and carboxylic acid groups) with surfaces containing complementary reactive groups. ${ }^{11,12}$ In both cases the protein is attached to the surface in random orientations. ${ }^{13}$ The use of recombinant affinity tags addresses the orientation issue. However, in most cases the interactions of the tags are reversible (e.g., glutathione S-transferase, maltose binding protein and poly-His ${ }^{6,14,15}$ ) and therefore not stable over the course of subsequent assays or require large mediator proteins (e.g., biotin-avidin and antigen antibody ${ }^{16-20}$ ).

Covalent attachment and orientation of a protein to a solid support requires two unique and 
mutually reactive groups on the protein and the support surface. The reaction between these two groups should be highly chemoselective, thus behaving like a molecular 'velcro'. Also, the reaction should work under physiological conditions (i.e. in aqueous buffers around $\mathrm{pH} 7$ ) in order to avoid the denaturation of the protein during the coupling step. Finally, it is desirable that the reactive group on the protein could be obtained using recombinant protein expression techniques.

The scope of this work is to review some of the methods most commonly employed as well as the latest developments for the chemoselective immobilizing proteins onto surfaces.

\section{Chemoselective attachment and its requirements}

The principle of chemoselectivity, sometimes referred as orthogonality, is fundamental to modern protein chemistry, and it describes the ability to selectively modify one functional group in the presence of other chemical groups. In order to be useful for protein attachment the corresponding reaction must happen between a unique chemical group present or introduced in the protein with a complementary group contained on a surface where the protein will be attached (see Fig. 1). This reaction must not be affected by the presence of the other reactive groups in the protein (i.e. amino, carboxylic acid, thiol and hydroxyl). In this way the protein is specifically attached to the surface through a unique reacting moiety which provides control of the orientation of the protein on the surface. Also, the reaction between the two complementary groups has to be compatible with physiological conditions (i.e. aqueous buffers at neutral $\mathrm{pH}$ ) in order to avoid the denaturation of the protein during the coupling step. Furthermore, since most of the proteins can only be obtained through recombinant methods, it also desirable to have an easy and general way to introduce these reactive groups into the protein using protein expression techniques.

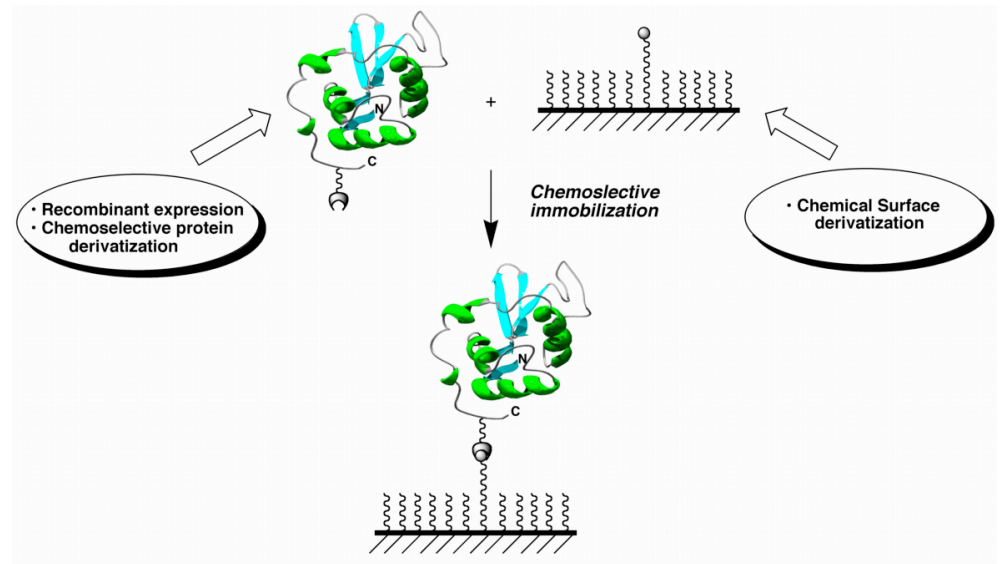

Fig. 1. General concept of chemoselective reaction between a protein and an appropriately chemically modified surface. 


\section{Short survey in chemical modification of surfaces}

When trying to attach proteins to surfaces the most common employed surfaces are silicon based (e.g. glass slides or $\mathrm{Si} / \mathrm{SiO}_{2}$ wafers) or metals (mainly Au and $\mathrm{Ag}$ ). The most used agent for chemically derivatizing silicon based surfaces is ( $\gamma$-aminopropyl)trialkoxylsilane (APS, see Fig. 2A $)^{21-23}$ which is relatively cheap and easy to handle. Moreover, the presence of the amine group allows to carry out a variety of subsequent chemical transformations to produce the desired complementary chemical moieties that will react with the appropriately modified protein. The reaction between the silane and the surface hydroxyl groups seems rather simple but is nevertheless rather complex. In aqueous solvents the amino group rapidly catalyzes the hydrolysis of the alkoxy groups. These hydrolyzed silane molecules do not only react easily with the surface silanol groups but also condense with each other to form siloxane oligomers. Remaining alkoxy groups and hydroxyl groups can form then hydrogen bonds with surface silanols and amine groups or form cross-links within the coupling layer (see Fig. 2B). Baking the silanized surface for a short period of time after the silanization process has been shown to help in increasing the degree of crosslinking and hence the hydrolytic stability of the corresponding surface. Structural investigations have shown, that in fact the APS molecules in these threedimensional polysiloxane networks can be in many conformations and orientations with respect to the surface and form definitely no monolayers. ${ }^{24}$ Ideal APS monolayers, as shown in Figure 2C, are only formed by vapor phase silanization techniques. ${ }^{21,22}$

A

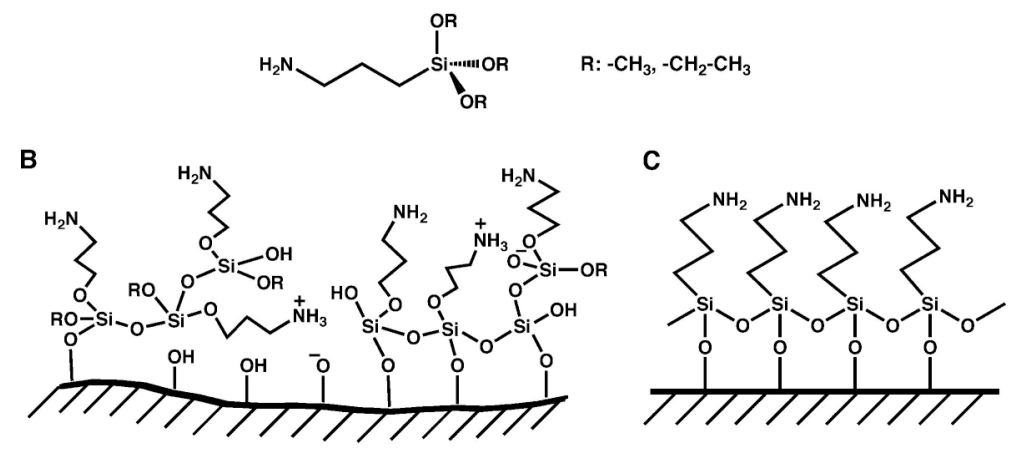

Fig. 2. Derivatization of silicon-based surface using ( $\gamma$-aminopropyl)trialkoxysilane (APS). (A) Structure of the APS molecule. (B) Schematic representation of a real APS multilayer obtained by liquid-phase deposition. (C) Schematic representation of an ideal APS monolayer.

Another approach to modify $\mathrm{SiO}_{2}$-based surfaces is to use long-chain trichlorosilanes. These molecules react faster with the silanol groups of the surface and also due to self-assembling character of the long alkyl chains, as result of the lateral van der Waal forces between the alky chains, are able to form densely packed highly ordered monomolecular assemblies with solidstate-like properties. ${ }^{25}$ Unfortunately, the use of APS analogues with long alkyl chains such as (17-aminoheptadecil)-trimethoxysilane, does not give rise to well ordered monolayers. ${ }^{26}$ This 
is very likely due to the hydrogen bond formation between the amine group and silanol surface. Proper chemical derivatization of the resulting monolayer can be achieved by using 1bromo-16-(trichlorosilyl)hexadecane, which forms close packed ordered monolayers. ${ }^{27}$ The bromo groups can be later substituted by azide anions which can be subsequently reduced to amine groups. Heise and co-workers ${ }^{28}$ have also shown that mixed self-assembled monolayers (also known as SAMs) can be used for tuning the concentration of amine groups on the surface (see Fig. 3). These amino groups can be easily derivatized with the desired complementary chemical group for the reaction with the adequate protein derivative. ${ }^{29}$

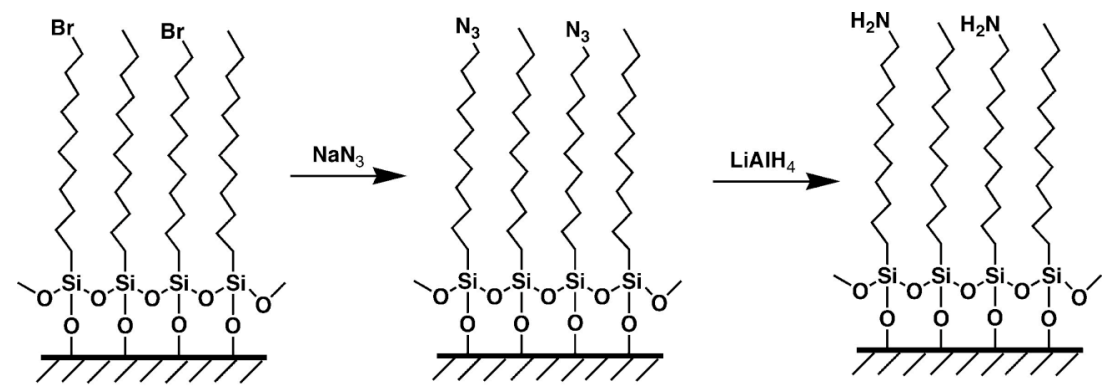

Fig. 3. Schematic representation of a mixed silane self-assembled monolayer (SAM) and subsequent in situ modification for the introduction of a primary amino group.

Another approach for derivatizing a surface suitable for the attachment of proteins is the use of a metal substrate like gold. ${ }^{29}$ Sulfur and selenium compounds have a strong affinity for this transition metal and they are also able to coordinate very strongly to other transition metals such as silver, copper and platinum. ${ }^{30}$

The most studied system, however, is the use of alkanethiols on $\mathrm{Au}(111)$ surfaces.

Chemisorption of alkanethiols as well as alkyl disulfides on clean gold gives rise to similar levels of surface coverage, although thiols react faster than disulfides. ${ }^{31}$ The reaction between the gold surface and the disulfide happens through a simple oxidative addition of the S-S bond to the gold surface:

$\mathrm{RS}-\mathrm{SR}+\mathrm{Au}_{n}^{0} \rightarrow 2 \mathrm{RS}^{-} \mathrm{Au}^{+} \cdot \mathrm{Au}_{n}^{0}$

In the alkanelthiol case, the reaction may be considered formally as an oxidative addition of the $\mathrm{S}-\mathrm{H}$ bond to the gold surface, followed by a reductive elimination of the hydrogen. When a clean surface is used this hydrogen probably ends as a $\mathrm{H}_{2}$ molecule:

$\mathrm{R}-\mathrm{S}-\mathrm{H}+\mathrm{Au}^{0}{ }_{n} \rightarrow \mathrm{R}-\mathrm{S}-\mathrm{Au}^{+} \cdot \mathrm{Au}^{0}{ }_{n}+1 / 2 \mathrm{H}_{2}$

The combination of hydrogen atoms at the metal surface to yield molecular hydrogen is thought to be an important exothermic step in the overall chemisorption energetics. The bonding of the thiolate to the gold surface is very strong (homolytic bond strength is 
approximately $\left.40 \mathrm{kcal} \mathrm{mol}^{-1}\right){ }^{32}$

Alkylaminothiols are the most common species used for the preparation of functionalized gold surfaces. Among them, cysteamine (HS- $\mathrm{CH}_{2}-\mathrm{CH}_{2}-\mathrm{NH}_{2}$ ) is probably the most used, ${ }^{33-36}$ in part due to its availability. Mercaptoalkyl carboxylic acids $\left(\mathrm{HS}-\left(\mathrm{CH}_{2}\right)_{\mathrm{x}}-\mathrm{CO}_{2} \mathrm{H}\right)$ ) can also be used to introduce a reactive group on the gold surface, ${ }^{36}$ however the amine group has slightly more potential than the carboxylic group for introducing chemical diversity on the surface.

As stated earlier for the silanes, the thiol molecule should contain long alkyl chains when ordered and packed surfaces are a requirement. Whitesides and coworkers ${ }^{14,15,37,38}$ have developed several chemical approaches for the synthesis of functionalized long chain alkane thiols. Key to all these approaches is the incorporation of a tri-(ethylene glycol) (TEG) moiety to the alkanethiol, which has been shown to decrease the non-specific adsorption of proteins to surfaces. ${ }^{8,38-40}$ In our group we have developed a new efficient solid-phase scheme for the rapid generation of modified long alkanethiols ${ }^{8,40}$ (see Fig. 4). The first step involves the immobilization of the corresponding $\omega$-mercaptoalkanoic acid on a trityl chloride resin. The thiol moiety of the carboxylic acid reacts selectively with the trityl chloride resin forming a thioether which results in the immobilization of the $\omega$-mercaptoalkanoic acid on the solidsupport. The free carboxylic function is then activated with HBTU (2-(1H-benzotriazole-1-yl)1,1,3,3-tetramethyuronium hexafluorophosphate) (HBTU) in DMF (dimethylformamide) after which is reacted with a mono-protected diamine. This step transforms the previous carboxylic function in a more versatile amino group. After the deprotection step, the amino group is then acylated with a TEG molecule incorporating both a protected amino and carboxylic groups. This step incorporates a TEG moiety to the thiolalkane at the same that keeps the amino group that can be then derivatized with the appropriate complementary reactive moiety. The final step involves the cleavage and deprotection of the product from the resin, which is accomplished by treatment with trifluoroacetic acid (TFA).

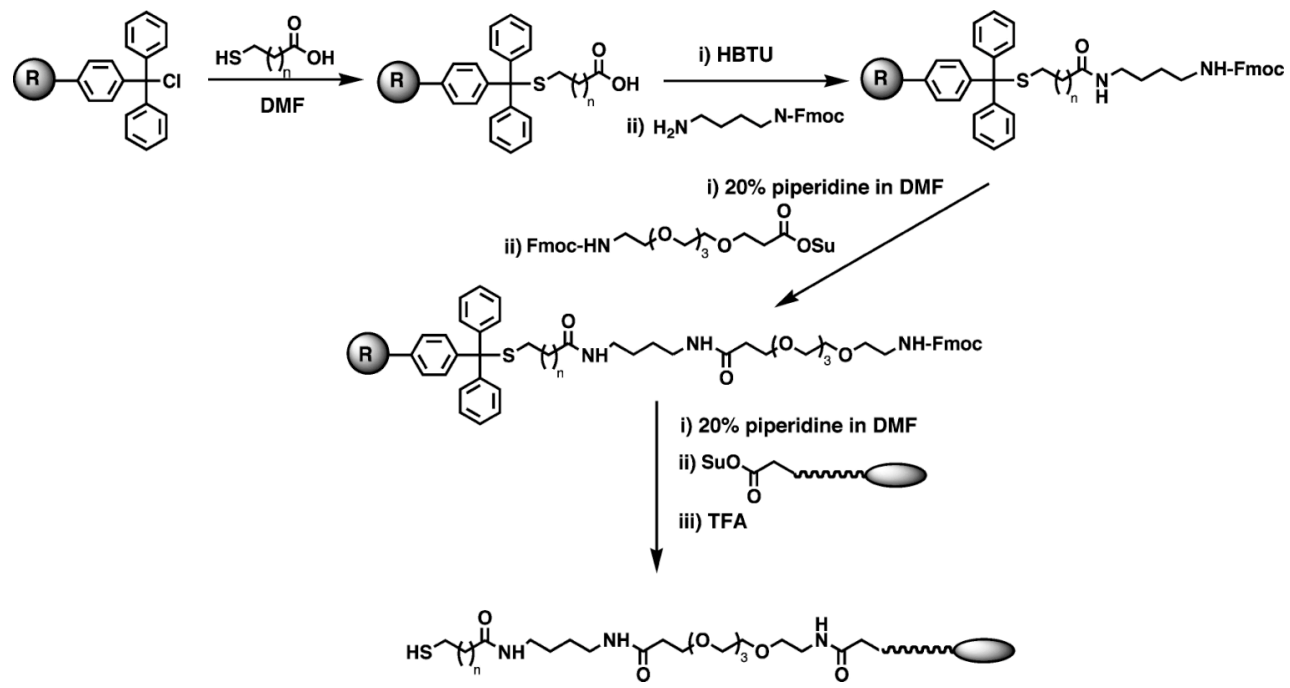

Fig. 4. Synthetic scheme developed in our group for the rapid and efficient preparation of chemically modified thioalkanes. In this case the solid ellipsoid represents the chemical group to be introduced in the surface. 


\section{Chemoselective attachment of proteins to surfaces}

Most of the methods suitable for the chemoselective attachment of proteins to surfaces are based on ligation methods originally developed for the synthesis, semi-synthesis and selective derivatization of proteins by chemical means. ${ }^{41-44}$ All these methods involve the derivatization of a protein with a unique chemical group at at a defined position, which will be later reacted chemoselectively with a complementary group previously introduced into the surface. In the following sections will review some of the most commomly employed as well as the more recently developed chemoselective reactions available to the biochemist.

\subsection{Immobilization of thiol-containing proteins}

Cysteine is the only amino acid containing a thiol group in its side-chain and its relative abundance in the average protein is rather small $(<2 \%)$. Thiols have a $\mathrm{p} K_{\mathrm{a}}$ of around 8.5 and they are nucleophilic at $\mathrm{pH} 7$. Under these conditions they can be reacted with high selectivity with some chemical groups like alkyl halides and maleimides compounds to form a stable thioether covalent bond (see Fig. 5).

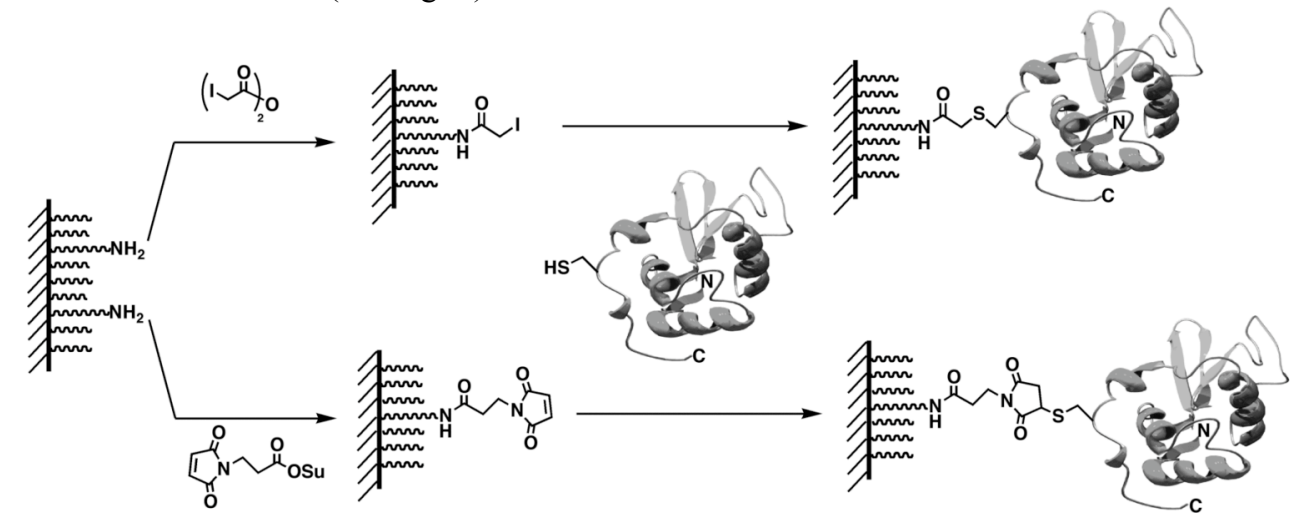

Fig. 5. Chemoselective reactions of the thiol group and its applications for attaching proteins to chemically modified surfaces containing an iodoacetamide or maleimide functions.

One of the most commonly used alkyl halide derivatives is the iodoacetyl group, which can be easily introduced on amine-modified surfaces through its symmetrical anhydride. ${ }^{45,46}$ It is important to remark that the iodoacetyl group can potentially react at neutral $\mathrm{pH}$ with other nucleophiles present in the protein (e.g., the imidazole ring of the His residue and the $\alpha$-amino group). However, when the iodoacetyl derivative is present in limiting quantities and the ligation is carried out at slightly alkaline $\mathrm{pH}$, the alkylation of the Cys thiol group will be the exclusive reaction.

Another thiol-reactive group is the maleimide function. The double bond of the maleimide function undergoes a selective addition reaction by the thiol group (see Fig. 5). This reaction is extremely selective in the $\mathrm{pH}$ range $6.5-7.5^{47}$ and only at higher $\mathrm{pH}$ values some cross- 
reactivity with amino groups may be observed. There are a great variety of commercial available reagents that can be used for introducing maleimide groups on an amine-derivatized surface. ${ }^{23}$ All of them contain both the maleimido and $N$-hydroxysuccinimide groups. This provides a unique window of reactivity for the chemoselective attachment of proteins to surfaces through the thiol group of the amino acid Cys. Hence, the only requirements are: (1) complementary reactive groups (i.e., maleimide or iodoacetyl groups) onto the appropriate surface and (2) a unique and reactive Cys residue on the protein.

Reactive Cys residues should not be involved in any structural element (i.e. disulfide bonds, Zn fingers, etc.) and should be exposed in solvent accessible region of the protein. In the absence of an endogenous Cys residue, it will be necessary to introduce a Cys residue through mutation of a native residue. The effect of this Cys mutation on the structure and function of the protein can be easily minimized by following a few simple rules: (1) if the tertiary structure of the protein is known, choose a region remote from the active site of the protein, preferably in a flexible surface loop; (2) choose the mutation to be as conservative as possible, e.g., $\mathrm{Ser} \rightarrow$ Cys or Ala $\rightarrow$ Cys; (3) avoid mutation of residues that are conserved across a gene family and (4) take advantage of any known mutational data on the system since the effect on structure/function of a specific residue mutations may already be known.

Bohn and co-workers ${ }^{21}$ have used this approach for the preparation of oriented citochrome b5 nanostructures on a Ti:Zn glass substrate. In this case the surface was silanized with APS and then the resulting amino group was acylated with EMCS ( $N$-hydroxy-succidinimyl 6maleimidocaproate). The maleimido group was then reacted chemoselectively with a mutant of cytochrome b5 where the natural residue Thr8 was mutated to Cys which produced an ordered protein film. The same authors also investigated the effect of the linker length on the orientation of proteins specifically attached through a unique Cys residue. ${ }^{48}$ For that purpose they used a genetically engineered myoglobin where the original residue Ala126 was mutated to Cys to introduce a unique thiol group in the protein. The mutated myoglobin was then reacted with self-assembled bromoalkylsilylated silica surfaces employing different linear alkyl chains varying in length. The results showed that the best ordering was accomplished with short $(n=2-3)$ and long $(n>11)$ alkyl chains. However, the stability of the protein was marginal when attached to long alkyl chains. This apparent instability was very likely due to the increased hydrophobic character of the surface. Edwards et al. ${ }^{49}$ used in this case the naturally occurring thiol group of the Cys 102 of yeast cytochrome $\mathrm{c}$ for the creation of a vectorially oriented monolayer of the bimolecular complex between yeast cytochrome $\mathrm{c}$ and bovine heart cytochrome $\mathrm{c}$ oxidase on both quartz and $\mathrm{Ge} / \mathrm{Si}$ multilayer substrates. In both cases the surfaces were silanized with APS (see Fig. 2) and then treated with EMCS. Xiao et $a l .{ }^{50,51}$ has also reported another example of selective attachment of a polypeptide through the thiol group of a Cys residue. In this case, two short cell-adhesive peptides containing single Cys residues were selectively immobilized onto a Ti surface previously treated first with APS and then with different maleimide amine-reactive compounds. More recently, Cheng et al. ${ }^{52}$ have also used a similar approach for the attachment of wild-type yeast cytochrome $\mathrm{c}$ to a $\mathrm{SiO}_{2}$-based surface using APS and the heterobifunctional crosslinker, $N$ - $[\gamma$-maleimidobutyryloxy]-sulfosuccinimide ester (sGMBS). The attached enzyme was linked to the surface through its natural residue Cys102. It is interesting to remark that the authors found that the 
immobilized protein was more resistant to denaturation by organic solvents than the free protein. Dill and co-workers ${ }^{53}$ have predicted that in some cases, the surface could in fact enhance the stability of the protein tertiary structure to a great extent. Spatial confinement such as that occurring on some surfaces may rise the barriers for all dynamic processes in the protein, including those favoring extended (i.e. denatured) confirmations and hence shifting the equilibrium from the unfolded state to the folded state..$^{53,54}$

Cheung et $\mathrm{al}_{.}{ }^{40}$ have also used a genetically modified Cow Pea Mosaic Virus (CPMV) to create assembled viral nanostructures on maleimide-containing surface templates. In this work the CPMV was genetically engineered to present Cys residues at geometrically equivalent positions in the solvent-exposed $\beta \mathrm{E}-\beta \mathrm{F}$ loop of the viral capsomer. ${ }^{55}$ The maleimide containing surface templates were created by microprinting techniques and scanning probe nanolithography on a gold coated mica surface using a PEGylated amino thiol linker (see Fig. 4). The amino group was then reacted with $N$-(maleimido-propionyloxy)-succinimide ester (MPS) to yield the corresponding maleimide-containing surface template. The Cys-mutated CPMV was chemoselectively attached only on those areas containing the maleimide function (see Fig. 6). Mirkin and co-workers ${ }^{56}$ have also used recently a similar scheme to template viral deposition on chemically modified surfaces.

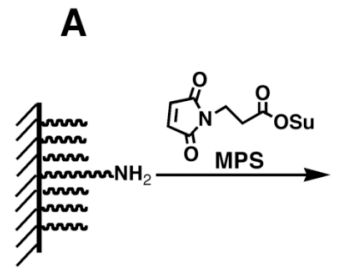

B

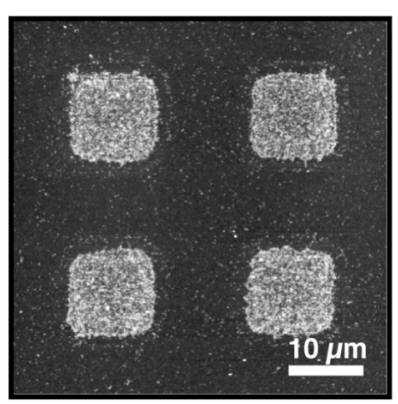

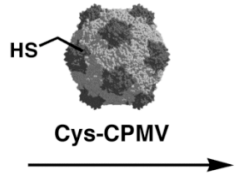

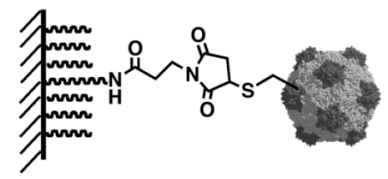

C

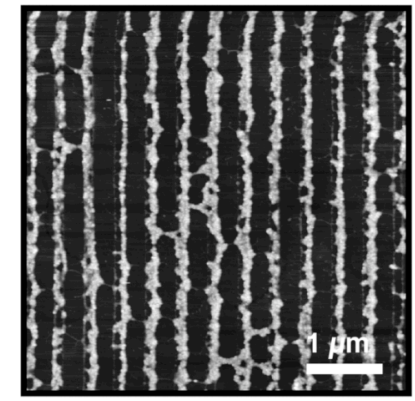

Fig. 6. (A) Chemoselective attachment of genetically modified CPMV virus with unique cysteine residues (Cys-CPMV). (B) Atomic force microscope (AFM) height image of Cys-CPMV virus assembled on a micron-sized template containing the maleimide function. (C) AFM height image of a monolayer-thick virions assembled on a parallel line pattern created by nanografting with a maleimide-containing linker. 
The thiol group can also react in an oxidative way with other thiols to form disulfides linkages. This approach has been used by several authors for attaching heme proteins containing single Cys residues to thiol-containing surfaces. ${ }^{21,57}$ The thiol group can be easily introduced on silicon-based surfaces using thiol alkylsilanes. However the disulfide linkage is less stable than the thioether bond described previously and can be easily reduced under slightly reductive conditions.

Other authors have used the thiol or the disulfide group as a way to attach proteins to an underivatized gold surface. As stated before, the thiol and disulfide groups can react with gold surfaces to form a relatively stable covalent bond. Aizawa and co-workers ${ }^{58}$ used this approach for attaching protein A fragments to a gold surface through a unique Cys residue introduced at the C-terminus of the protein fragment by genetic engineering. The resulting attached protein A fragment retained the same IgG binding activitiy as the intact protein A and it was used for the highly oriented immobilization of antibodies. Mirkin and co-workers ${ }^{59}$ have also used this

kind of covalent immobilization for the creation of nano-metric patterns using collagen-peptide fragments containing a unique Cys residue in combination with the atomic force microscopy technique of dip-pen nanolithography.

Cavarelly et al. ${ }^{60}$ also used the naturally occurring and unique disulfide bond present in the protein azurin. This protein was able to form highly ordered films when reacted with gold. In contrast, the same protein gave random orientations when adsorbed on a self-assembled monolayer of 11-mercaptoundecanoic acid on gold.

More recently Zare and co-workers ${ }^{61}$ have also attached yeast cytochrome $\mathrm{c}$ to a gold surface through the naturally occurring Cys102. The attachment was followed by surface plasma resonance (SPR). This technique was also used to follow the denaturation and renaturation of the attached enzyme with different concentrations of urea. Interestingly, the authors found that the immobilized protein could be reversibly denatured and renatured, depending on the urea concentration. Also, the Gibbs free energy change for renaturation $\left(\Delta G_{\text {water }}^{\circ}\right.$ ) of the attached protein was about 4 times less than the published value for the protein in solution. This difference could indirectly explain the decrease in biological activity observed when of cytochrome $\mathrm{c}$ is attached to a gold surface.

In summary, the use of the Cys thiol group for achieving ordered immobilization of proteins and virus onto solid surfaces is an approach that has been widely used by the scientific community. It should be noted, however, that is not general method and can be only applied when there is only one reactive Cys residue, either artificially introduced o naturally occurring, on the protein to be attached. When the protein contains multiple Cys residues it is better to use alternative chemoselective methods.

\subsection{Immobilization of carbonyl-containing proteins}

None of the genetically coded amino acids contain carbonyl groups (i.e., aldehyde and ketone groups) in the side-chain, only some glycoproteins which have been post-translationally modified by glycosylation with reductive sugars.

The carbonyl function reacts at $\mathrm{pH} 5-6$ very efficiently and selectively with hydrazine and 
hydroxylamine-containing substances to yield the relatively stable hydrazones and oximes, respectively (note that aldehydes react faster than ketones due to sterical reasons). The hydrazone function can be further stabilized by mild reduction with $\mathrm{NaBH}_{4}$ (sodium borohydride) or $\mathrm{NaBH}_{3} \mathrm{CN}$ (sodium cyanoborohydride). These two facts open the possibility of using these well known chemical reactions for the selective attachment of proteins to solid supports with total control over the orientation.

A
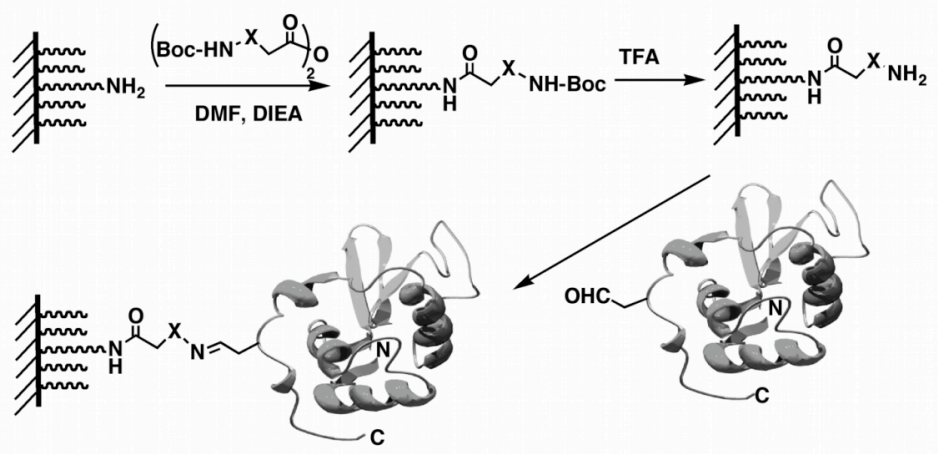

B

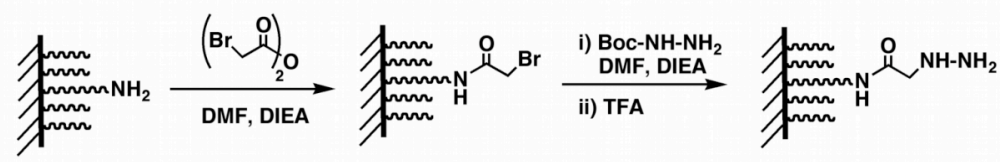

Fig. 7. Chemoselective reactions involving a carbonyl group. (A) Attachment of a protein through its carbonyl group to a surface containing a hydrazine $(\mathrm{X}=-\mathrm{NH}-)$ or an aminoxy $(\mathrm{X}=-\mathrm{O}-)$ group. (B) Alternative approach for the introduction of a hydrazine function into an amine-containing surface using 2-bromoacetic acid and $t$ butyl carbazate.

The only requirements are the introduction of a unique carbonyl group in a well defined and solvent accessible position on the protein surface and the preparation of a hydrazine- or hydroxylamine-containing chemical surface. The hydrazine and hydroxylamine function can be easily introduced onto an amine-containing surface using the corresponding symmetrical anhydrides of the $\mathrm{N}$-protected hydrazinoacetic acid (Boc-NH-NH- $\mathrm{CH}_{2}-\mathrm{CO}_{2} \mathrm{H}$ ) or $\mathrm{N}$-protected aminoxyacetic acid (Boc- $\left.\mathrm{NH}-\mathrm{O}-\mathrm{CH}_{2}-\mathrm{CO}_{2} \mathrm{H}\right)$ as depicted in Figure 7A. The hydrazino group can be also easily introduced onto an aminated surface by using 2-bromoacetic acid and $t$ butyl carbazate (see Fig. 7B). The hydrazide function also readily reacts with carbonyl groups (see Fig. 8) and can be easily introduced onto a silicon-based surface by using first thiolalkylsilanes and then a heterobifunctional crosslinker such as $\mathrm{MBPH}^{62}$ (4-(4- $\mathrm{N}$ maleimidophenyl)-butyric acid hydrazide, see Fig. 8). In this case the maleimido group reacts selectively with the thiol-covered surface to introduce the hydrazide function onto the surface, which can react with any carbonyl-containing protein to give a highly ordered protein film (see Fig. 7). Carbonyl groups can also reversibly react with amino groups to give the corresponding 
imines, which can be reduced with $\mathrm{NaBH}_{3} \mathrm{CN}$ to provide more stable amine derivatives.

The most common method of introducing a carbonyl function into a protein is by mild sodium periodate oxidation. Oxidation of 1,2-diols (present in the polysaccharide chain of glycoproteins) and $\beta$-aminoethanol derivatives (N-terminal Ser and Thr residues contain a $\beta$ aminoethanol function) to the corresponding aldehydes derivatives. The periodate anion also oxidizes Met (to its sulfoxide) and thiol groups (usually to disulfides). These reactions, however, occur at slower rates than the oxidation of 1,2-diols and $\beta$-aminoethanol derivatives. Another milder procedure for introducing carbonyl groups into glycoproteins is the use of specific sugar oxidases. These enzymes only catalyze the oxidation of a specific monosaccharide and not with other sugars present in the polysaccharide chain. The most often used oxidase for this purpose is galactose oxidase, which forms C-6 aldehydes on terminal Dgalactose or N-acetyl-D-galactose residues. ${ }^{63,64}$ When galactose residues are penultimate to sialic acid, another enzyme, the enzyme neuramidase is used first to remove the sialic residue thus exposing the galactose residue for the enzymatic oxidation. Using these two independent methods, the sugar moiety of glycoproteins (including antibodies) can be oxidized to introduce selectively aldehyde groups in the glycosylation site of the protein.

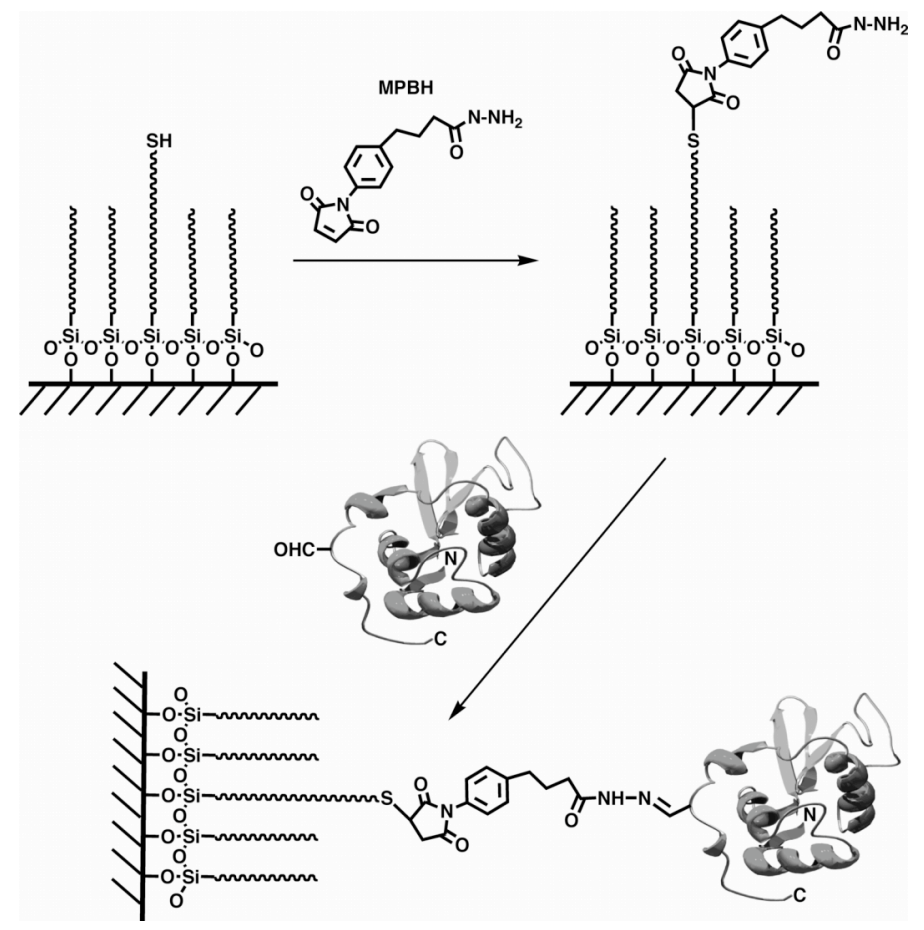

Fig. 8. Site-derected immobilization of carbonyl-containing proteins on glass by using the 4-(4- $N$ maleimidephenyl)-butyric acid hydrazide (MBPH) heterofunctional crosslinker. 
Proteins containing $N$-terminal Ser or Thr residues can also be selectively oxidized to yield aldehyde groups. ${ }^{65-67}$ PCR-driven mutagenesis can be used for the introduction of the dipeptide Met-Ser/Thr- at the $N$-terminus of recombinant protein (note that the Met residue is always the first amino acid to be translated by the ribosome). Once the protein has been fully translated, the Met residue is then removed in vivo by the endogenoeus methionine aminopeptidase (MAP) enzyme yielding the corresponding $N$-terminal Ser or Thr residue. ${ }^{68}$ Verdine and co-workers ${ }^{69}$ have also used an enzymatic approach for introducing a $N$-terminal Ser residue into a protein. The leader peptide sequence Met-Ile-Glu-Gly-Arg-Ser was introduced by PCR-driven mutagenesis at the $N$-terminus of the original protein. This added extra sequence contains a Factor Xa proteolysis site which can be selectively cleaved after the Arg residue to yield the corresponding protein containing a $N$-terminal Ser residue. Tolbert and Wong ${ }^{70}$ have also showed that the cysteine protease from Tobacco Etch Virus (TEV) can be used for the same purpose. This protease is highly specific and it can be overexpressed in $E$. coli. Other proteases that cleave at the $\mathrm{C}$-terminal side of their recognition site, like enterokinase and ubiquitin $C$-terminal hydrolase, could be also used for the generation of $N$ terminal Ser residues. More recently, Schultz and co-workers ${ }^{71}$ have evolved an orthogonal tRNA-synthetase pair that makes possible the efficient incorporation of a keto amino acid , $p$ acetylphenylanine, into proteins in $E$. coli with high translational fidelity in response to the amber nonsense codon.

The chemoselective attachment of a protein through a carbonyl function is the method most commonly used for the attachment of antibodies to solid surfaces. ${ }^{19}$ Antibodies are glycosylated symmetrically at the Fc fragment and can be mildy oxidized with sodium periodate or the corresponding glyco-oxidase to yield an aldehyde function at the glycosylation site. For example, Muchova et al. ${ }^{72}$ have been able to immobilize a monoclonal antibody directed against the carcinoembryonic cell adhesion molecule I (CECAM1) on a hydrazideactivated cellulose. This support was obtained by treating partially oxidized cellulose with adipic acid dihydrazide. The monoclonal antibody was first oxidized with periodate and then bound to the hydrazide-activated matrix through its glycosylation site. This functionalized cellulose substrate was then used for the purification of CECAM1 protein by affinity chromatography. Using a similar approach, Bilkova et al. ${ }^{73}$ have been able to immobilize galactose oxidase through its carbohydrate chain to hydrazide-activated cellulose beads. The sugar moiety of the enzyme was oxidized with periodate to yield the reactive aldehyde function.

Some other authors have used the amine function instead the hydrazide function for attaching carbonyl-containing proteins to surfaces. ${ }^{74,75}$ It is important to remark, however, that in this case the linkage between the protein and the surface (i.e., an imine function) is not stable unless is reduced with mild reductive agents such as $\mathrm{NaBH}_{3} \mathrm{CN}$. Reductive treatments of proteins may sometimes reduce the disulfide bonds of the protein, which may result in its biological inactivation. Note that antibodies contain several disulfide bonds which are essential for the stabilization of their tertiary and quaternary structure.

\subsection{Immobilization through the protein C-terminus by using Expressed Protein Ligation}

One the most efficient ways to attach biologically active proteins to surfaces through their C- 
termini is by using Expressed Protein Ligation (EPL) ${ }^{8}$ Key to this approach is the use of protein $\alpha$-thioesters which can be efficiently attached to surfaces containing $N$-terminal Cys residues through Native Chemical Ligation (NCL, see Fig. 9). In this reaction, independently developed by $\mathrm{Kent}^{76}$ and $\mathrm{Tam}^{77}$, two fully unprotected polypeptides, one containing an Cterminal $\alpha$-thioester group and the other an $N$-terminal Cys residue, react chemoselectively under neutral aqueous conditions with the formation of a native peptide bond at the ligation site (see Fig. 9A). The initial step in this ligation involves the formation of a thioester-linked intermediate, which is generated by a transthioesterification reaction involving the $\mathrm{C}$-terminal thioester moiety of one fragment and the $\mathrm{N}$-terminal Cys thiol group of the other. This intermediate then spontaneously rearranges to produce a native peptide bond at the ligation site. This type of thioester-based chemistry was first pioneered by Wieland in 1950's for the synthesis of small Cys-containing peptides. ${ }^{78}$ Note that only N-terminal Cys residues thioesterintermediates can rearrange to the final amide bond. The non N-terminal Cys thioesters are non-productive and can be simply converted back to starting materials by including small amounts of a thiol cofactor in the reaction mixture. Polypeptide C-terminal $\alpha$-thioesters can also react very efficiently with other $N$-nucleophiles such as hydrazine and aminoxy functions to yield the corresponding hydrazides and hydroxamates. ${ }^{79}$ These reactions can be performed
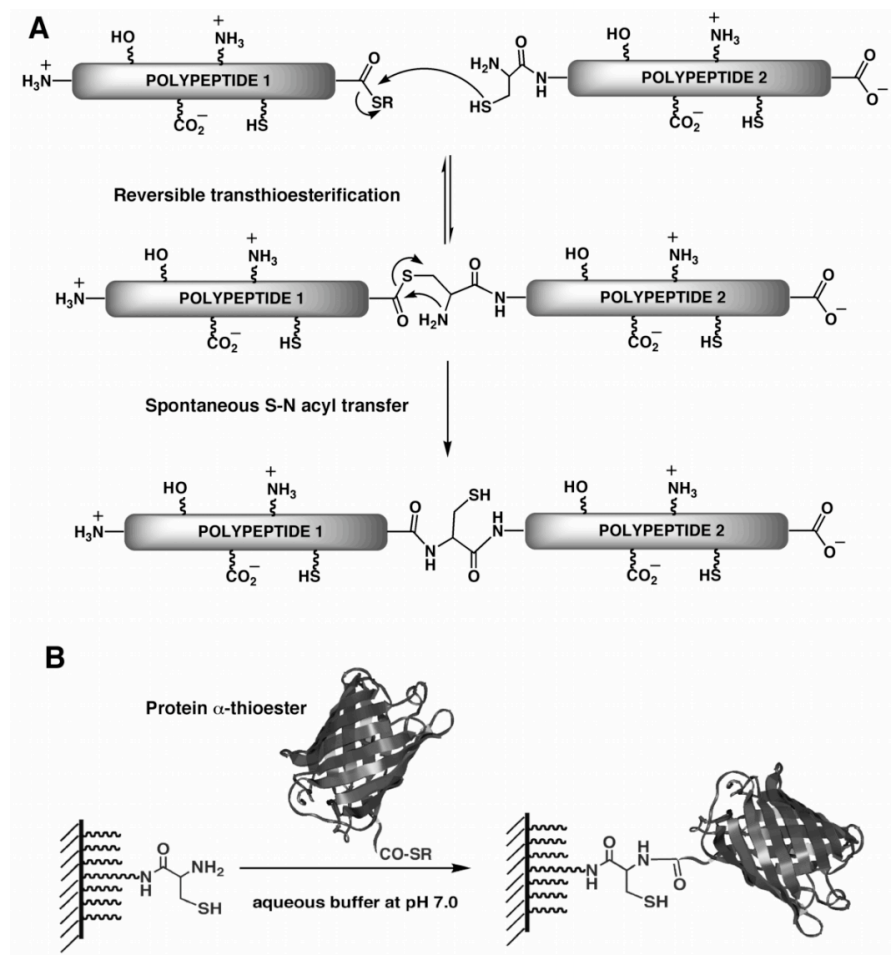

Fig. 9. (A) Principle of Native Chemical Ligation (NCL). (B) Site-specific attachment of a protein $\alpha$-thioester through its $\mathrm{C}$-terminus by Expressed Protein Ligation (EPL). 
A

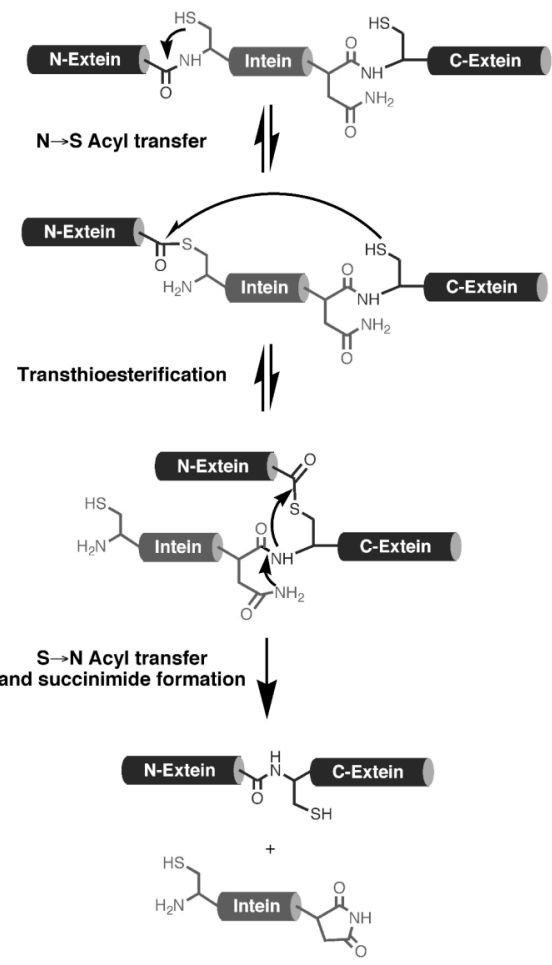

B

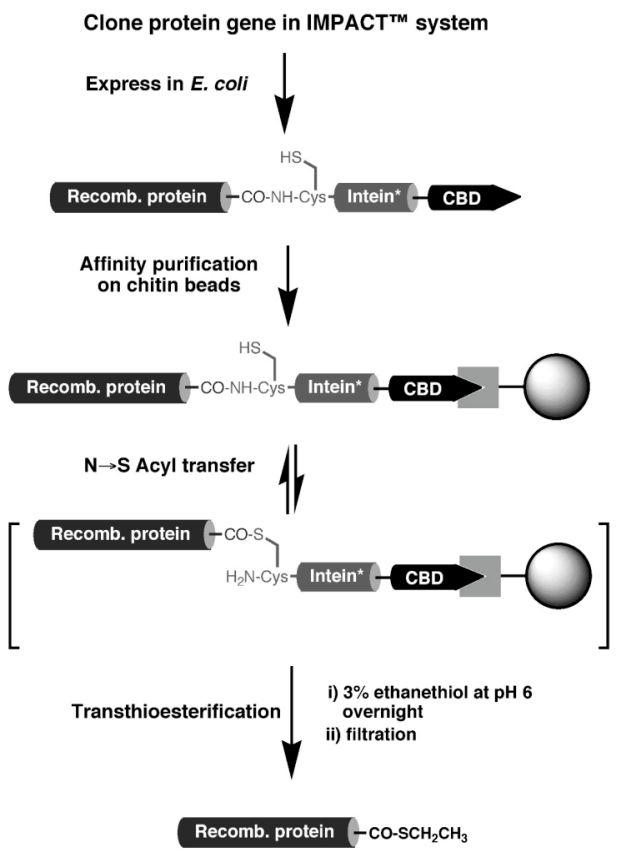

Fig. 10. Biosynthetic preparation of C-terminal $\alpha$-thioester proteins. (A) Proposed mechanism of protein splicing. (B) Expression, purification and cleavageof a protein-intein*-CBD fusion protein (the asterisk denotes mutation of the conserved Asn residue to Ala) with the appropriate thiol to yield an $\alpha$-thioester protein.

at $\mathrm{pH}$ 6-7 in the presence of the functional groups normally present in a protein without any kind of interference.

The elucidation of the protein splicing mechanism by Perler and co-workers ${ }^{80}$ has made the production of recombinant $C$-terminal $\alpha$-thioester proteins possible by a modification of this naturally occurring splicing process. ${ }^{46,81-83}$ Protein splicing is a cellular processing event that occurs post-translationally at the polypeptide level. In this multistep process an internal polypeptide fragment, called intein, is self-excised from a precursor protein which allows the ligation of the flanking protein sequences ( $N$ - and $C$-exteins) to give a different protein (see Fig. 10A). The current understanding of the mechanism involves the formation of thioester/ester intermediates. ${ }^{84}$ The first step in the splicing process involves an $N \rightarrow S$ or $N \rightarrow O$ acyl shift in which the $N$-extein is transferred to the thiol/alcohol group of the first residue of the intein. After the initial $N \rightarrow(S / O)$ acyl shift, a trans esterification step follows in which the $\mathrm{N}$-extein is transferred to the side-chain of a second conserved Cys, Ser or Thr residue located at the junction between the intein and the $C$-extein. The amide bond at this junction is then 
broken as a result of succinimide formation involving a conserved Asn residue within the intein. In the final step of the process, a peptide bond is formed between the $N$-extein and $C$ extein following an $(S / O) \rightarrow N$ acyl shift.

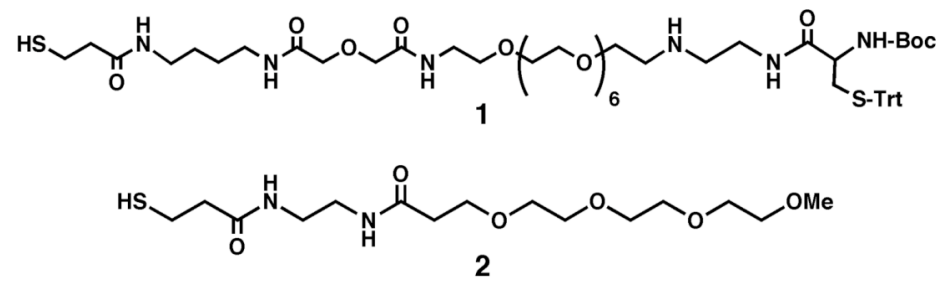

Fig. 11. PEGylated thiol linkers used to attach $C$-terminal $\alpha$-thioester proteins to acryloxy-modified glass surfaces (see Fig, 12).

Mutation of the conserved Asn residue within the intein to Ala blocks the splicing process in midstream thus resulting in the formation of an $\alpha$-thioester linkage between $N$-extein and the intein $^{85}$ (see Fig. 10B). This thioester bond can be cleaved using an appropriate thiol to give the corresponding $\alpha$-thioester $N$-extein through a transthioesterfication reaction. The IMPACT expression system, commercially available from New England Biolabs (www.neb.com), ${ }^{86,87}$ allows the generation of recombinant $\alpha$-thioester proteins by making use of such modified inteins in conjunction with a chitin binding domain (CBD) for easy purification by affinity chromatography (see Fig. 10B).

We have recently immobilized several biologically active proteins onto a modified glass surfaces through their $C$-termini using this approach. ${ }^{8}$ Two fluorescent proteins (EGFP and DsRed) and a SH3 domain protein C-terminal $\alpha$-thioesters were readily expressed in $E$. coli using an intein expression system. The $\alpha$-thioester proteins were then efficiently immobilized onto a $N$-terminal Cys-containing glass slide. The chemical modification of the glass slide was accomplished first by silanization with (3-acryloxypropyl)-trimethoxysilane and then reacting

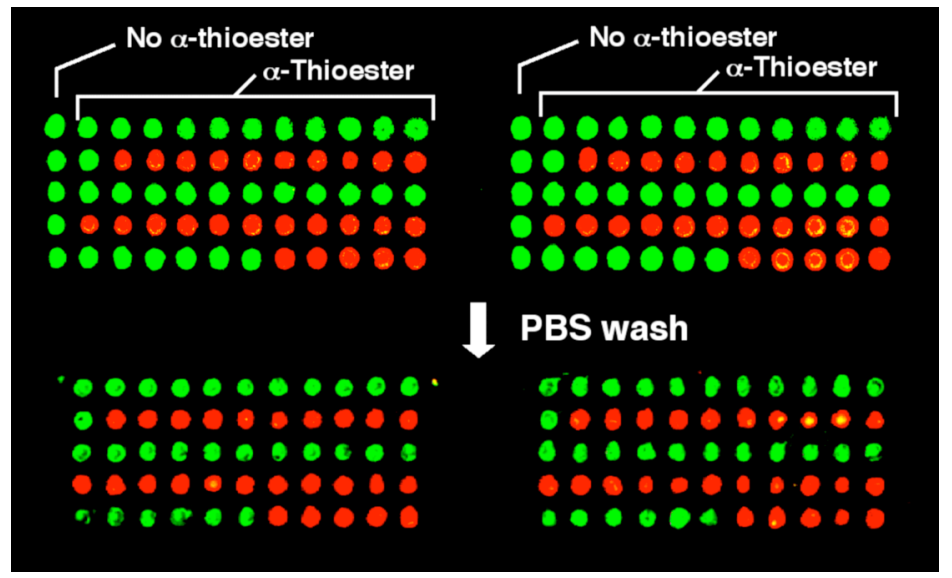

Fig. 12. Selective attachment of EGFP (green) and DsRed (red) $\alpha$-thioesters onto a Cys-containing glass slide. Epifluorescence image of the glass slide after the protein spotting (top) and after PBS (phosphate buffer solution) washes (botton). EGFP with no $\alpha$-thioester was used as control. Spotting was carried out using $100 \mu \mathrm{M}$ protein solutions. 
with a mixture of PEGylated thiol linkers 1 and 2 (see Fig. 11), in a molar ratio of 1:5, respectively. Linker 1 contained a protected $N$-terminal Cys residue for the selective attachment of the $\alpha$-thioester proteins meanwhile linker $\mathbf{2}$ was used as diluent to control the number of reactive sites on the surface. Linker 1 also contains a longer PEG moiety than linker 2 to ensure that the reactive Cys groups were readily available to react with the corresponding protein $\alpha$-thioester in solution. When the derivatization was complete, the protecting groups $(N$-Boc and $S$-Trt) of the Cys residue from linker 1 were removed by a brief treatment with trifluoroacetic acid. The surface was rinsed, neutralized and quickly used for spotting (see Fig. 12). The ligation reaction was kept at $36 \mathrm{~h}$ in the dark at room temperature and the proteinmodified slide was then extensively washed. As shown in Figure 12, only specific attachment between the $\alpha$-thioester proteins and the Cys-containing glass surface was observed. No fluorescence signal was observed where the control EGFP protein lacking an $\alpha$-thioester was spotted. It is interesting to note that the immobilized DsRed protein, which only has red fluorescence as a tetramer, retained its red fluorescence thereby indicating that its quaternary architecture was unaffected by the attachment to the PEGylated glass surface.

\subsection{Attachment through the protein $\mathrm{N}$-terminal amino group}

The $\alpha$-amino group of a protein can react with a carbonyl group under slightly acidic $\mathrm{pH}(\approx 5)$ to yield the corresponding imine. However, as we have seen earlier, the imine function is

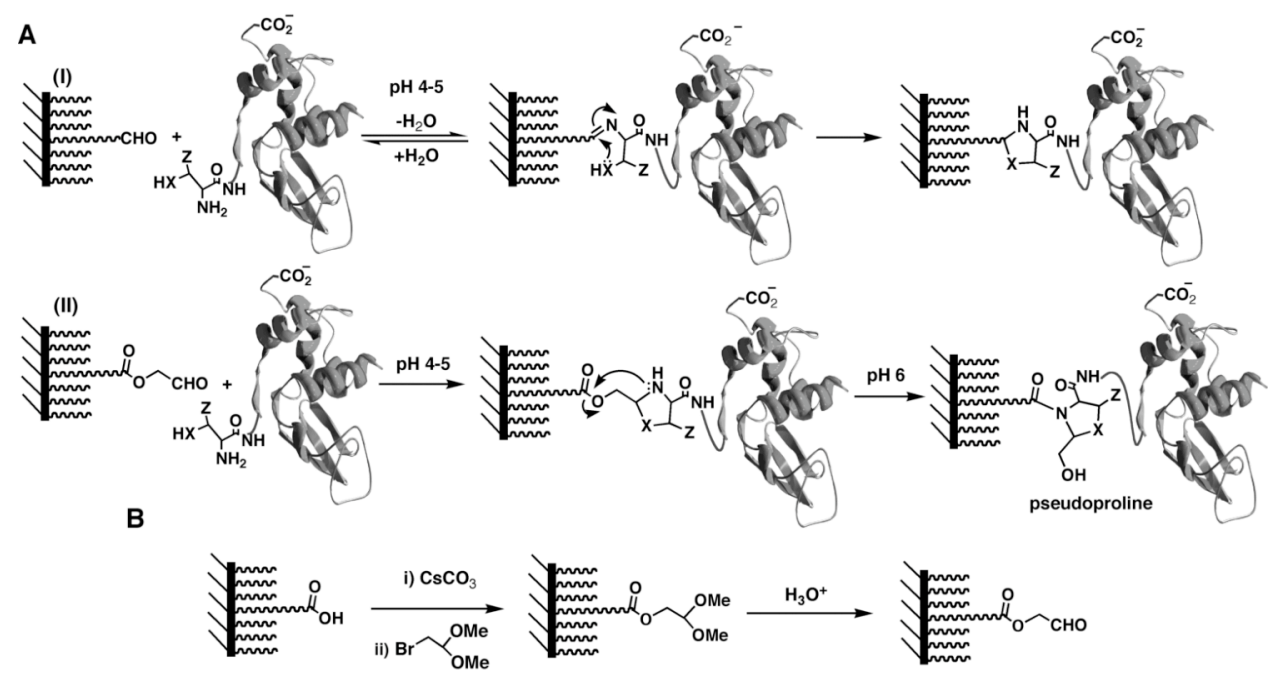

Fig. 13. Selective attachment of a protein through its $N$-terminus to a carbonyl-containing surface. (A) Chemoselective reaction between an $N$-terminal Ser $(X=\mathrm{O}$ and $\mathrm{Z}=\mathrm{H})$, Thr $\left(\mathrm{X}=\mathrm{O}\right.$ and $\left.\mathrm{Z}=\mathrm{CH}_{3}\right)$ or Cys $(\mathrm{X}=\mathrm{S}$ and $\mathrm{Z}=\mathrm{H}$ ) protein and a surface containing the aldehyde (I) or a glycol aldehyde ester (II) functionalities. $\mathbf{B}$. Introduction of a glycol aldehyde ester on a surface modified to contain a carboxylic acid functionality. The glycoaldehyde group is introduced on the carboxylic group by esterification between the carboxylate cesium salt and the bromoacetaldehyde dimethyl acetal. The free aldehyde is released by acidic hydrolysis. 
rather unstable and can not be used as a stable linkage for attaching proteins onto surfaces. One exception to this rule, however, is when the $N$-terminal amino acid of a protein is either Cys, Ser or Thr (note that all these amino acids contain an heteroatom, either oxygen or sulfur, in $\beta$ position to the $\alpha$-amino group). In these cases the initially formed imine reacts intramolecularly with the heteroatom through a favorable 5-member ring transition state to give the relatively stable thiazolidine or oxazolidine ring (see Fig. 13). Tam and coworkers ${ }^{88,89}$ have further developed this reaction by using a glycol aldehyde ester (see Fig. 13A). In this case the nitrogen on the thiazolidine (or oxazolidine) ring attacks the ester function through a favorable 5-member ring transition state to finally give a very stable pseudo-proline linkage.

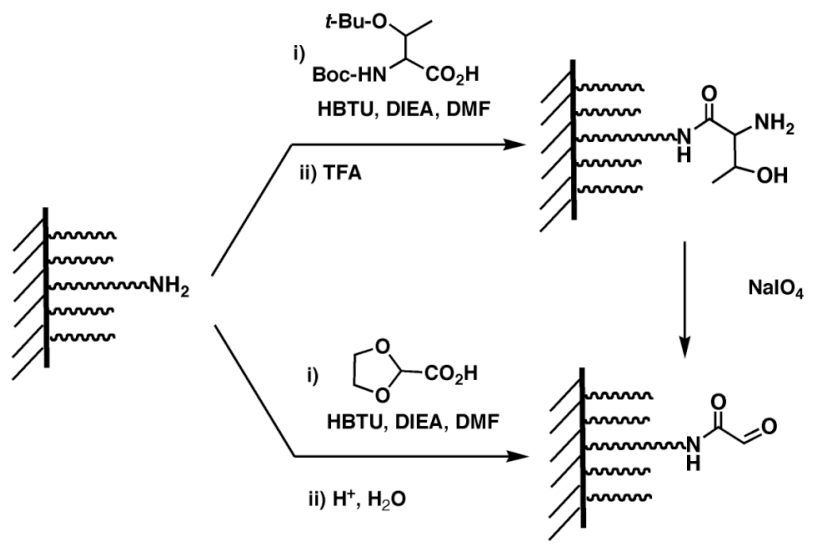

Fig. 14. Introduction of the aldehyde functionality onto an aminated surface. (A) In this approach the first step involves the acylation of the amino group with the activated $\operatorname{Boc}-\operatorname{Ser}(t-\mathrm{Bu})-\mathrm{OH}$ amino acid derivative. Once the coupling has been completed, the Boc- and $t$-butyl protecting group is deprotected by treatment with trifluoroacetic acid (TFA) and then oxidized with $\mathrm{NaIO}_{4}$ to yield the corresponding aldehyde. (B) An alternative approach involves the acylation of the amine-containing surface with the ethylenglycol acetal of the glyoxylic acid. Once the coupling step has been carried out the acetal protecting group is removed by acidic hydrolysis yielding back the aldehyde function.

These two reactions are extremely chemoselective and therefore can be used for the attachment of proteins to an aldehyde-containing surface through its $\mathrm{N}$-terminus under relatively mild conditions. The aldehyde function can be directly introduced into a silicon-based surface by using the commercially available aldehyde-containing 4-oxo-butyltrialkylsilane ${ }^{11}$ or by indirect means using an aminated-silicon surface (see Fig. 14) ${ }^{90}$. On the other hand, recombinant proteins containing $N$-terminal Ser, Thr or Cys residues can be easily obtained by using different specific proteolytic approaches as described earlier.

As we have seen already in the previous section, $N$-terminal Cys polypeptides can also react very efficiently at neural $\mathrm{pH}$ with $\alpha$-thioesters. Yao and co-workers ${ }^{18}$ have used this approach for the immobilization of small $\mathrm{N}$-terminal Cys-containing polypeptides onto a thioestermodified surface through NCL. 


\subsection{Immbobilization using the Staudinger ligation reaction}

A modification of the so-called Staudinger reaction has been recently developed by two groups independently. ${ }^{91-94}$ This reaction allows the chemoselective formation of an amide bond between an arylphosphine moiety and azide group (see Fig. 15A). The reaction proceeds by the nucleophilic attack of an arylphosphine on the azide group to form a reactive aza-ylide intermediate. The acyl group then traps the ylide intermediate in an intramolecular fashion, resulting in an amide-linked phosphine oxide after hydrolysis. In the modified version of this reaction the attack of the ylide on the acyl group cleaves also at the same time the arylphosphine moiety yielding at the end a neat amide bond formation (see Fig. 15B). This reaction is highly chemoselective and works with better yields when $\mathrm{Z}$ is $-\mathrm{CH}_{2}-$ (note that in this case the transition state during the intramolecular rearrangement is again a favorable 5membered ring) and $\mathrm{X}$ is sulfur (i.e. a thioester function).

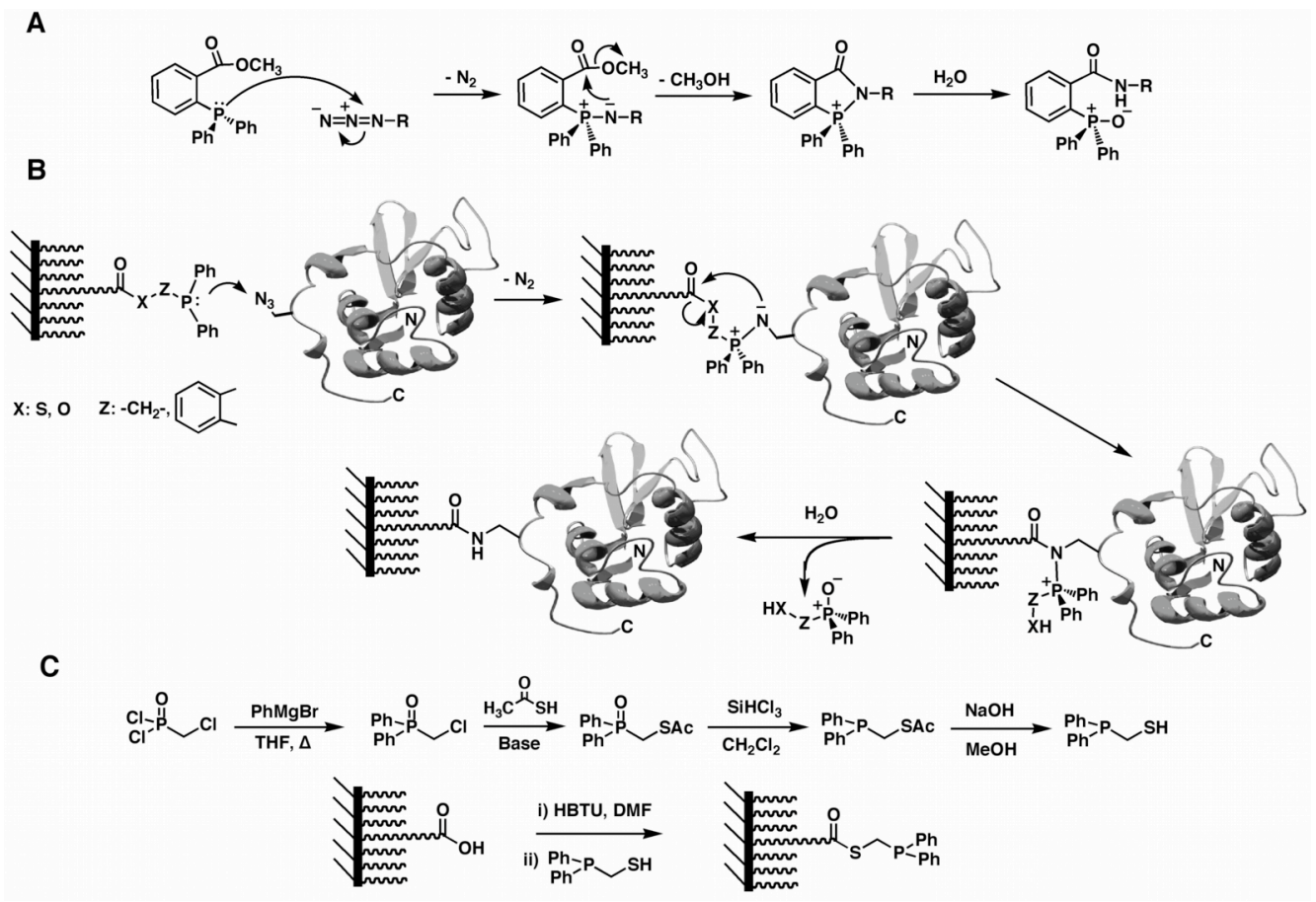

Fig. 15. Chemoselective attachment of proteins to surfaces by using a modification of the Staudinger reaction. (A) Proposed mechanism for the Staudinger reaction. (B). Attachment of a polypeptide to solid surface by using a modified version of the Staudinger reaction. (C) Synthetic scheme for modifying a carboxylic surface with a suitable phosphinothiol for the Staudinger ligation reaction. 
The introduction of the arylphosphine derivative in carboxylic-containing surface can be conveniently carried out (see Fig. 15C) by using an activated carboxylic surface and the diphenylphosphinomethanethiol which synthesis has been recently reported by Raines and coworkers $^{95}$ for the immobilization of small azide-containing synthetic polypeptides onto glass slides.

The azide function is not present in any naturally occurring protein. However, Bertozzi and co-workers, ${ }^{96}$ have recently reported a novel method for incorporation of azide groups into recombinant proteins. They showed the unnatural amino acid azido-homoalanine, a surrogate of methionine, can be loaded into the methionyl-tRNA synthetase of $E$. coli and incorporated in recombinant proteins expressed in methionine depleted bacterial cultures by using a methionine auxotroph $E$. coli strain. It is important to note, however, that this approach would only work if the protein only contains a unique solvent accessible (i.e., reactive) methionine residue. Otherwise, multiple solvent accessible azide groups would be incorporated in the corresponding protein and therefore the control over the orientation during the attachment would be lost. It is also important to remember that the first amino acid to be translated by the ribosome during the biosysthesis of any protein is always a methionine residue and this residue is efficiently removed by the endogenous methionine aminopeptidase only when the second residue is Gly, Ala, Pro, Ser, Thr, Val or Cys. ${ }^{68}$ In all the remaining cases the $N$-terminal methionine will not be cleaved efficiently thus providing a unique methionine residue in proteins when no additional Met residues are exposed.

\section{Chemoenzymatic methods for the site-specific attachment of proteins to surfaces}

All the methods described so far rely on pure chemoselective reactions with little or not entropic activation at all. That means that the efficiency of these reactions depends strongly on the concentration of the reagents (i.e. on the concentration of the protein to be attached to the corresponding surface) to bring close enough both reactants in order to allow them to react in an extremely efficient way.

A way to overcome this intrinsic entropic barrier and make ligation reactions more efficient, even under high dilution, is through the introduction of complementary moieties in the protein and the surface, which can form a stable and specific intermolecular complex. Once formed, this complex brings both reactive groups in close proximity thus increasing the local effective of both reactants. This increment in local effective concentration results in the efficient and selective covalent attachment of the protein to the surface even under diluted conditions (see Fig. 16). This effect has been already reported to improve the rate of several intermolecular ${ }^{97,98}$ and intramolecular ${ }^{45,99}$ protein chemical ligation reactions under high dilution conditions.

The main advantages of using this approach are: (1) the requirement of considerable less protein since the ligation reaction works very efficiently even under high dilution conditions; and (2) no need for purification since at high dilution the only protein that will react with the surface will be the one having the complementary affinity and reactive tag (see Fig. 16). 


\subsection{Immobilization by using active site-directed capture ligands}

This approach relies on producing a recombinant fusion protein which contains a capture protein (usually an enzyme) as well as the protein of interest to be immobilized at the surface.

The surface is modified to contain a ligand (usually a substrate for the enzyme) that would be specifically recognized by the capture protein. This ligand is designed to contain a reactive group which, once the complex is formed, will react covalently with the capture protein thus leading to the immobilization of the fusion protein.
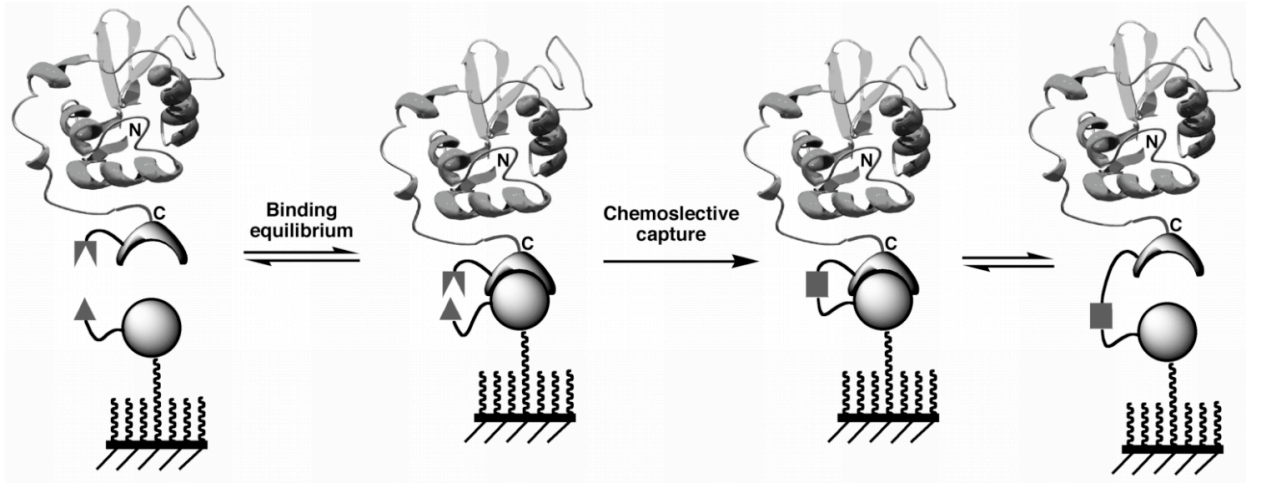

Fig. 16. Attachment of a protein to a surface by using an entropically assisted chemoselective reaction.

The idea of using reactive ligands to capture proteins has been used by Meares and coworkers ${ }^{100}$ for creating antibodies with infinite affinity. In this interesting work, the authors created an antibody against a metal-complex ligand which contained a reactive electrophile close to the binding site. When the antibody and the ligand are apart, their complementary groups do not react (mainly due to the dilution effect). However, when the antibody specifically binds the ligand, the effective concentration of their complementary groups is greatly increased thus leading to the irreversible formation of a covalent bond.

More recently, Mrksich and co-workers ${ }^{101}$ have used this same principle for the selective attachment of protein onto surfaces with total control over the orientation (see Fig. 17). In their approach, they used the protein calmodulin fused with the enzyme cutinase as a capture protein. Cutinase is a $22 \mathrm{kDa}$ serine esterase that is able to form a site-specific covalent adducts with chorophosphonate ligands. ${ }^{102}$ The chlorophosphonate group mimics the tetrahedral transition state of an ester hydrolysis. When it binds specifically to the active site of the enzyme, the hydroxyl group of the catalytic serine residue reacts covalently with the chlorophosphonate to yield a stable covalent adduct that is resistant to hydrolysis (see Fig. 17B). In this case the authors used a gold surface to immobilize the cutinase inhibitor. The attachment is extremely selective and can be carried with the whole crude E. coli periplasmic 
lysate containing the cutinase fusion protein thus demonstrating that there is no need to purify the protein before the immobilization step. ${ }^{101}$ This approach has been also recently used for the preparation of antibody arrays on self-assembled monolayers presenting a phosphonate capture ligand. ${ }^{103}$

Walsh and co-workers ${ }^{104}$ have also recently reported a very elegant scheme for the chemoenzymatic site-specific modification of proteins. In their approach the target proteins are expressed as fusions to a peptide carrier protein (PCP) excised from a nonribosomal peptide synthetase (NRPS). NRPS PCPs are 8-10 kDa autonomously folded, compact and stable domains. These domains contain one specific Ser residue that can be catalitically phosphorylated by the phosphopenateinyl (Ppant) transferase SFP using CoA (Coenzyme A) as substrate. Using the Ppant transferase SFP from B. subtilis, the authors were able to specifically label proteins with Ppant-biotin using biotin-CoA as substrate. These biotinlabeled proteins were used to produce protein microarrays onto an avidin-coated glass slide. In a similar way this approach could be used for the site-specifi immobilization of PCP-fusion proteins onto surfaces derivatized by CoA.
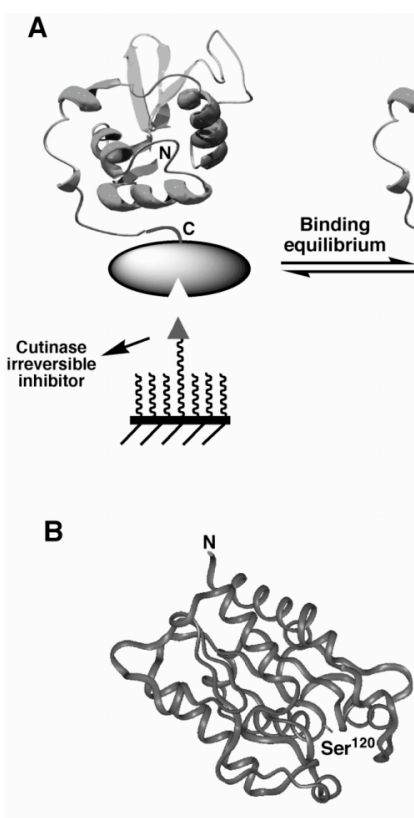
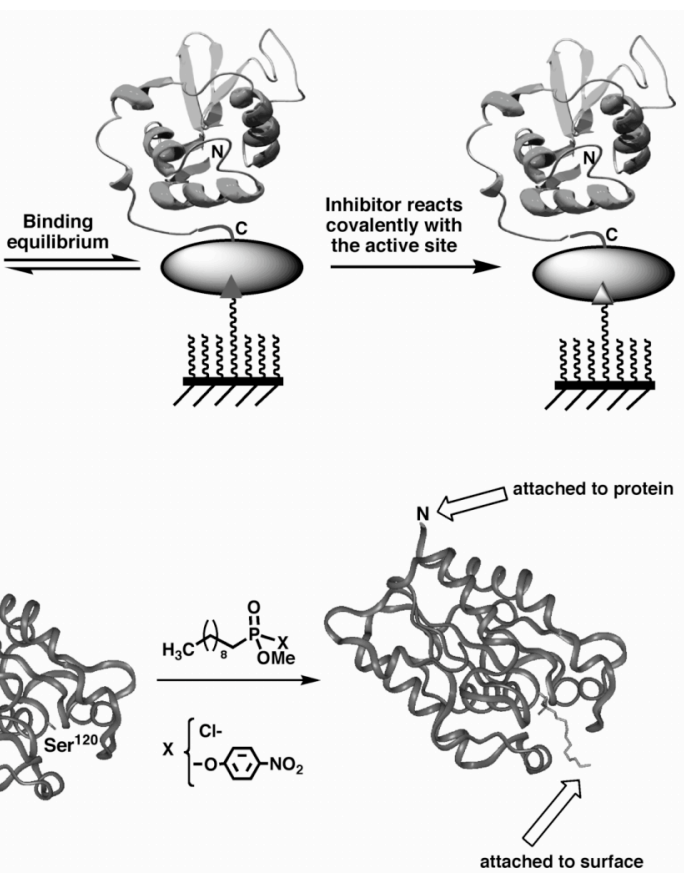

Fig. 17. Attaching proteins to a surface by using an active-site directed capture ligand approach. (A) Principle of the active-site directed capture ligand approach. (B) Structure of $F$. solani cutinase enzyme free and bound to the inhibitor $n$-undecyl-O-methyl phosphonate chloride. The inhibitor is covalently bound through the sidechain hydroxyl group of the Ser120 residue which is located at the active site of the enzyme. 


\subsection{Immobilization by using protein trans-splicing}

The main limitation of the previous methods, however, is that the linker between the protein of interest and the surface is always another protein or protein domain. In some cases, the presence of such a big linker could potentially give rise to some problems, specially in those applications where the attached protein will be involved in studying protein/protein interactions with complex protein mixtures, ${ }^{6,105}$ mainly due to potential cross-reactivity issues.

In order to address this problem, our group is of developing a new method for the chemoenzymatic attachment of proteins to surfaces based on the protein trans-splicing process (see Fig. 18). This process is similar to the protein splicing described earlier (see Fig. 9A) with the only difference that the intein self-processing domain is split in two fragments (called $\mathrm{N}$ intein and $C$-intein, respectively). ${ }^{106,107}$ These two intein fragments alone are inactive.

However, they can bind each other with high affinity under the appropriate conditions yielding a totally functional splicing domain.

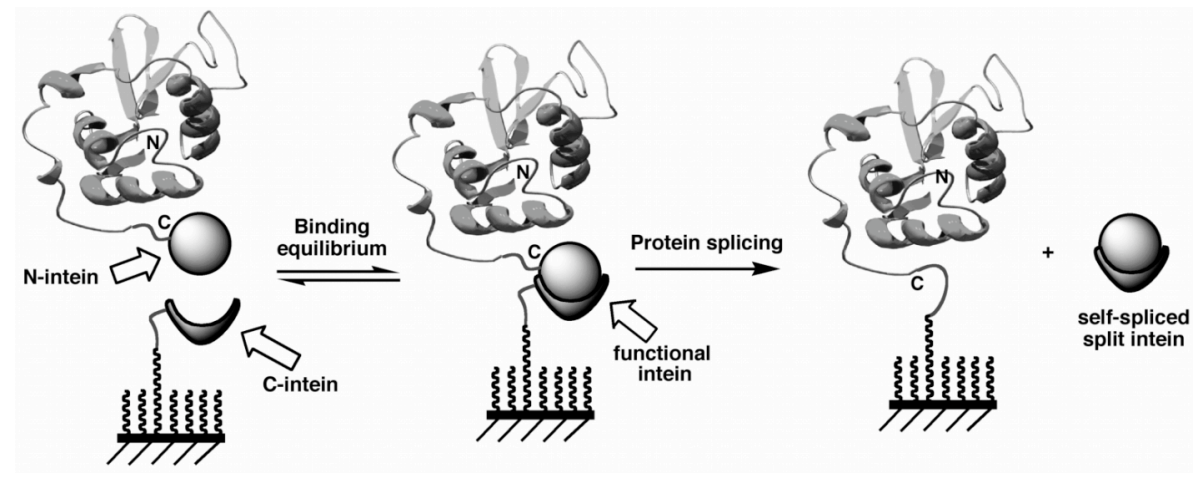

Fig. 18. Site-specific immobilization of proteins through its $C$-termini to a solid surface by using a protein transsplicing technique.

In our approach, one of the fragments ( $C$-intein) is covalently attached to the surface through a small peptide-linker while the other fragment ( $N$-intein) is fused to the $\mathrm{C}$-terminus of the protein to be attached to surface. When both intein fragments interact, they form the active intein which ligates the protein of interest to the surface at the same time the split intein is spliced out into solution (see Fig. 18).

\section{Conclusions and Perspectives}

In this review, we have summarized several of the most commonly used as well as the latest developments in chemoselective reactions for the controlled attachment and orientation of proteins onto solid surfaces. As mentioned earlier, the ability to attach proteins to a solid support in an ordered fashion will play a critical role in biology and biophysics. For example, 
the creation of functional protein microarrays is critical for the progress in proteomics research. $^{2,3,108,109}$ Like DNA chips, protein chips will allow the analysis and screening of thousand of proteins simultaneously, which will promote the discovery of new drug targets. Moreover, it should be relatively easy to employ protein chips to screen potential drug candidates for unwanted side-effects in all the metabolic pathways.

Protein chips can also be also used as a diagnosis tool for profiling protein expression in order to find potential potentially relevant biomarkers. ${ }^{109}$ Another potential application for ordered protein films on surfaces will be the production of optimized biosensors. ${ }^{110,111}$ An ordered protein film has a higher activity density than a random protein film, where a significant percentage of the protein molecules bound to the surface are potentially inactive conformations. This will allow biosensor miniaturization without losing sensitivity.

Also, the combination of recent nano-lithography techniques combined with the ability to bind proteins in extremely ordered fashion will allow the creation of protein nanopatterns which could be used as templates for the crystallization of biomolecules. This emerging technology is expected to have a significant impact in structural biology field as the main bottleneck in this field is obtaining suitable crystals for physical studies.

In summary, protein biochips furnish us with very powerful tools that will shape the future of biology and biophysics.

\section{Acknowledgments}

Support was provided by the U.S. Department of Energy by the University of California, Lawrence Livermore National Laboratory under contract No. W-7405-Eng-48.

\section{References}

1. D. H. Min and M. Mrksich, Curr. Opin. Chem. Biol. 8, 554 (2004).

2. B. Schweitzer, P. Predki and M. Snyder, Proteomics 3, 2190 (2003).

3. E. Phizicky, P. I. Bastiaens, H. Zhu, M. Snyder and S. Fields, Nature 422, 208 (2003).

4. H. Zhu and M. Snyder, Curr. Opin. Chem. Biol. 7, 55 (2003).

5. G. MacBeath, Nat. Genet. 32 Suppl, 526 (2002).

6. H. Zhu, M. Bilgin, R. Bangham, D. Hall, A. Casamayor, P. Bertone, N. Lan, R. Jansen, S. Bidlingmaier, T. Houfek, T. Mitchell, P. Miller, R. A. Dean, M. Gerstein and M. Snyder, Science 293, 2101 (2001)

7. H. Zhu and M. Snyder, Curr. Opin. Chem. Biol. 5, 40 (2001).

8. J. A. Camarero, Y. Kwon and M. A. Coleman, J. Am. Chem. Soc. 126, 14730 (2004).

9. K. B. Lee, S. J. Park, C. A. Mirkin, J. C. Smith and M. Mrksich, Science 295, 1702 (2002).

10. P. Arenkov, A. Kukhtin, A. Gemmell, S. Voloshchuk, V. Chupeeva and A. Mirzabekov, Anal. Biochem. 278, 123 (2000).

11. G. MacBeath and S. L. Schreiber, Science 289, 1760 (2000).

12. G. Y. Liu and N. A. Amro, Proc. Natl. Acad. Sci. U. S. A. 99, 5165 (2002).

13. T. Cha, A. Guo and X. Y. Zhu, Proteomics 5, 416 (2005).

14. G. B. Sigal, C. Bamdad, A. Barberis, J. Strominger and G. M. Whitesides, Anal. Chem. 68, 490 (1996). 
15. N. H. Thomson, B. L. Smith, N. Almqvist, L. Schmitt, M. Kashlev, E. T. Kool and P. K. Hansma, Biophys. J. 76, 1024 (1999).

16. M. Saleemuddin, Adv. Biochem. Eng. Biotechnol. 64, 203 (1999).

17. L. J. Holt, C. Enever, R. M. de Wildt and I. M. Tomlinson, Curr. Opin. Biotechnol. 11, 445 (2000).

18. M. L. Lesaicherre, R. Y. Lue, G. Y. Chen, Q. Zhu and S. Q. Yao, J. Am. Chem. Soc. 124, 8768 (2002).

19. P. Peluso, D. S. Wilson, D. Do, H. Tran, M. Venkatasubbaiah, D. Quincy, B. Heidecker, K. Poindexter, N. Tolani, M. Phelan, K. Witte, L. S. Jung, P. Wagner and S. Nock, Anal. Biochem. 312, 113 (2003).

20. R. Y. Lue, G. Y. Chen, Y. Hu, Q. Zhu and S. Q. Yao, J. Am. Chem. Soc. 126, 1055 (2004).

21. H.-G. Hong, M. Jiang, S. G. Sligar and P. W. Bohn, Langmuir 10, 153 (1994).

22. D. G. Kurth and T. Bein, Langmuir 11, 3061 (1995).

23. G. MacBeath, A. N. Koehler and S. L. Schreiber, J. Am. Chem. Soc. 121, 7967 (1999).

24. F. J. Boerio, L. Armogan and S. Y. Cheng, J. Colloid Interface Sci. 1980, 416 (1980).

25. M. Pomerantz, A. Segmuller, L. Netzer and J. Sagiv, Thin. Solid Films 132, 153 (1985).

26. K. Bierbaum, M. Kinzler, C. Woll, M. Grunze, G. Hahner, S. Heid and F. Effenberger, Langmuir 11, 512 (1995).

27. N. Balachander and C. N. Sukenik, Langmuir 6, 1621 (1990).

28. A. Heise, H. Menzel, H. Yim, M. D. Foster, R. H. Wieringa, A. J. Schouten, V. Erb and M. Stamm, Langmuir 13, 723 (1997).

29. T. P. Sullivan and W. T. S. Huck, Eur. J. Org. Chem. 2003, 17 (2003).

30. A. Ulman, Chem. Rev. 96, 1533 (1996).

31. H. A. Biebuyck, C. D. Bian and G. M. Whitesides, Langmuir 10, 1825 (1994).

32. L. H. Dubois and R. G. Nuzzo, Ann. Phys. Chem. 43, 437 (1992).

33. P. Wagner, M. Hegner, H.-J. Guntherodt and G. Semenza, Langmuir 11, 3867 (1995).

34. C.-M. Yam, C. M. Pradier, M. Salmain, P. marcus and G. Jaouen, J. Colloid Interface Sci. 235, $183(2001)$.

35. K. Uvdal and T. P. Vikinge, Langmuir 17, 2008 (2001).

36. Y. C. Liu, C. M. Wang and K. P. Hsiung, Anal. Biochem. 299, 130 (2001).

37. C. Pale-Grosdemange, E. Simon, K. L. Prime and G. M. Whitesides, J. Am. Chem. Soc. 113, 12 (1991).

38. E. Ostuni, R. C. Chapman, M. N. Liang, G. Meluleni, G. Pier, D. E. Ingber and G. M. Whitesides, Langmuir 17, 6336 (2001).

39. E. Ostuni, R. G. Chapman, R. E. Holmlin, S. Takayama and G. M. Whitesides, Langmuir 17, 5605 (2001).

40. C. L. Cheung, J. A. Camarero, B. W. Woods, T. W. Lin, J. E. Johnson and J. J. De Yoreo, J. Am. Chem. Soc. 125, 6848 (2003).

41. M. Kohn and R. Breinbauer, Angew. Chem. Int. Ed. Engl. 43, 3106 (2004).

42. T. W. Muir, Annu. Rev. Biochem. 72, 249 (2003).

43. J. P. Tam, J. X. Xu and K. D. Eom, Biopolymers 60, 194 (2001).

44. S. Aimoto, Curr. Org. Chem. 5, 45 (2001).

45. J. A. Camarero, G. J. Cotton, A. Adeva and T. W. Muir, J. Pept. Res. 51, 303 (1998).

46. J. A. Camarero and T. W. Muir, Current Protocols in Protein Science 18.4, 1 (1999).

47. M. D. Partis, D. G. Griffiths, G. C. Roberts and R. B. Beechey, J. Protein Chem. 2, 263 (1983).

48. M. A. Firestone, M. L. Shank, S. G. Sligar and P. W. Bohn, J. Am. Chem. Soc. 118, 9033 (1996).

49. A. M. Edwards, J. K. Blasie and J. C. Bean, Biophys. J. 74, 1346 (1998).

50. S. J. Xiao, M. Textor, N. D. Spencer and H. Sigrist, Langmuir 14, 5507 (1998). 
51. S. J. Xiao, S. Brunner and M. Wieland, J. Phys. Chem. 108, 16508 (2004).

52. Y. Y. Cheng, H. C. Chang, G. Hoops and M. C. Su, J. Am. Chem. Soc. 126, 10828 (2004).

53. H. X. Zhou and K. A. Dill, Biochemistry 40, 11289 (2001).

54. A. P. Minton, Curr. Opin. Struct. Biol. 10, 34 (2000).

55. Q. Wang, L. Tianwei, T. Liang, J. E. Johnson and M. G. Finn, Angew. Chem. Int. Ed. 41, 459 (2002).

56. J. C. Smith, K. B. Lee, Q. Wang, M. G. Finn, J. E. Johnson, M. Mrksich and C. A. Mirkin, Nano Lett. 3, 883 (2003).

57. L. L. Wood, S. S. Cheng, P. L. Edmiston and S. S. Saavedra, J. Am. Chem. Soc. 119, 571 (1997).

58. S. Kanno, Y. Yanagida, T. Haruyama, E. Kobatake and M. Aizawa, J. Biotechnol. 76, 207 (2000).

59. D. L. Wilson, R. Martin, S. Hong, M. Cronin-Golomb, C. A. Mirkin and D. L. Kaplan, Proc. Natl. Acad. Sci. U. S. A. 98, 13660 (2001).

60. O. Cavalleri, C. Natale, M. E. Stroppolo, A. Relini, E. Cosulich, S. Thea, M. Novi and A. Gliozzi, Phys. Chem. Chem. Phys. 2000, 4630 (2000).

61. S. Chah, C. V. Kumar, M. R. Hammond and R. N. Zare, Anal. Chem. 76, 2112 (2004).

62. V. H. Routh and C. J. Helke, J. Neurosci. Methods 71, 163 (1997).

63. D. C. Gowda, Biochem. Biophys. Res. Commun. 245, 28 (1998).

64. Q. Fu and D. C. Gowda, Bioconjug. Chem. 12, 271 (2001).

65. H. F. Gaertner, R. E. Offord, R. Cotton, D. Timms, R. Camble and K. Rose, J. Biol. Chem. 269, 7224 (1994).

66. H. F. Gaertner and R. E. Offord, Bioconjug. Chem. 7, 38 (1996).

67. R. E. Offord, H. F. Gaertner, T. N. Wells and A. E. Proudfoot, Meth. Enzymol 287, 348 (1997).

68. P. H. Hirel, M. J. Schmitter, P. Dessen, G. Fayat and S. Blanquet, Proc. Natl. Acad. Sci. U.S.A. 86, 8247 (1989).

69. D. A. Erlandson, M. Chytil and G. L. Verdine, Chem. Biol. 3, 981 (1996).

70. T. J. Tolbert and C.-H. Wong, Angew. Chem. Int. Ed. Engl. 41, 2171 (2002).

71. L. Wang, Z. Zhang, A. Brock and P. G. Schultz, Proc. Natl. Acad. Sci. U. S. A. 100, 56 (2003).

72. L. Muchova, M. Jirsa, M. Kuroki, L. Dudkova, M. J. Benes, Z. Marecek and F. Smid, Biomed. Chromatogr. 15, 418 (2001).

73. Z. Bilkova, M. Slovakova, A. Lycka, D. Horak, J. Lenfeld, J. Turkova and J. Churacek, J. Chromatogr. B 770, 25 (2002).

74. W. P. Quian, B. Xu, L. Wu, C. X. Wang, D. F. Yao, F. Yu, C. W. Yuan and Y. Wei, J. Colloid Interface Sci. 214, 16 (1999).

75. W. P. Quian, D. Yao, B. Xu, F. Yu, Z. Lu and W. Knoll, Chem. Mater. 11, 1399 (1999).

76. P. E. Dawson, T. W. Muir, I. Clark-Lewis and S. B. H. Kent, Science 266, 776 (1994).

77. J. P. Tam, Y. A. Lu, C. F. Liu and J. Shao, Proc. Natl. Acad. Sci. U. S. A. 92, 12485 (1995).

78. T. Wieland, E. Bokelmann, L. Bauer, H. U. Lang and H. Lau, Liebigs Ann. Chem. 583, 129 (1953).

79. J. A. Camarero, A. Adeva and T. W. Muir, Lett. Pept. Sci. 7, 17 (2000).

80. S. Chong, Y. Shao, H. Paulus, J. Benner, F. B. Perler and M. Q. Xu, J. Biol. Chem. 271, 22159 (1996).

81. T. W. Muir, D. Sondhi and P. A. Cole, Proc. Natl. Acad. Sci. U. S. A. 95, 6705 (1998).

82. K. Severinov and T. W. Muir, J. Biol. Chem. 273, 16205 (1998).

83. T. C. Evans, J. Benner and M.-Q. Xu, Protein Sci. 7, 2256 (1998).

84. C. J. Noren, J. M. Wang and F. B. Perler, Angew. Chem. Int. Ed. 39, 451 (2000).

85. F. B. Perler and E. Adam, Curr. Opin. Biotechnol. 377 (2000). 
86. S. Chong, F. B. Mersha, D. G. Comb, M. E. Scott, D. Landry, L. M. Vence, F. B. Perler, J. Benner, R. B. Kucera, C. A. Hirvonen, J. J. Pelletier, H. Paulus and M. Q. Xu, Gene 192, 271 (1997).

87. S. Chong, G. E. Montello, A. Zhang, E. J. Cantor, W. Liao, M. Q. Xu and J. Benner, Nucleic Acids Res. 26, 5109 (1998).

88. C.-F. Liu and J. P. Tam, Proc. Natl. Acad. Sci. U.S.A. 91, 6584 (1994).

89. C.-F. Liu, C. Rao and J. P. Tam, J. Am. Chem. Soc. 118, 307 (1996).

90. J. R. Falsey, M. Renil, S. Park, S. Li and K. S. Lam, Bioconjug. Chem. 12, 346 (2001).

91. E. Saxon, J. I. Armstrong and C. R. Bertozzi, Org. Lett. 2, 2141 (2000).

92. E. Saxon and C. R. Bertozzi, Science 287, 2007 (2000).

93. B. L. Nilsson, L. L. Kiessling and R. T. Raines, Org. Lett. 3, 9 (2001).

94. M. Kohn and R. Breinbauer, Angew. Chem. Int. Ed. Engl. 43, 3106 (2004).

95. M. B. Soellner, K. A. Dickson, B. L. Nilsson and R. T. Raines, J. Am. Chem. Soc. 125, 11790 (2003).

96. K. L. Kiick, E. Saxon, D. A. Tirrell and C. R. Bertozzi, Proc. Natl. Acad. Sci. U S A 99, 19 (2002).

97. G. S. Beligere and P. E. Dawson, J. Am. Chem. Soc. 121, 6332 (1999).

98. L. Minakhin, J. A. Camarero, M. Holford, C. Parker, T. W. Muir and K. Severinov, J. Mol. Biol. 306, 631 (2001).

99. J. A. Camarero and T. W. Muir, J. Am. Chem. Soc. 121, 5597 (1999).

100. A. J. Chmura, M. S. Orton and C. F. Meares, Proc. Natl. Acad. Sci. U. S. A. 98, 8480 (2001).

101. C. D. Hodneland, Y. S. Lee, D. H. Min and M. Mrksich, Proc. Natl. Acad. Sci. U. S. A. 99, 5048 (2002).

102. M. L. Mannesse, J. W. Boots, R. Dijkman, A. J. Slotboom, H. T. van der Hijden, M. R. Egmond, H. M. Verheij and G. H. de Haas, Biochim. Biophys. Acta 1259, 56 (1995).

103. Y. Kwon, Z. Han, E. Karatan, M. Mrksich and B. K. Kay, Anal. Chem. 76, 5713 (2004).

104. J. Yin, F. Liu, X. Li and C. T. Walsh, J. Am. Chem. Soc. 126, 7754 (2004).

105. H. Zhu, J. F. Klemic, S. Chang, P. Bertone, A. Casamayor, K. G. Klemic, D. Smith, M. Gerstein, M. A. Reed and M. Snyder, Nat. Genet. 26, 283 (2000).

106. B. M. Lew, K. V. Mills and H. Paulus, J. Biol. Chem. 273, 15887 (1998).

107. F. B. Perler, Trends Biochem. Sci. 24, 209 (1999).

108. P. F. Predki, Curr. Opin. Chem. Biol. 8, 8 (2004).

109. R. Barry and M. Soloviev, Proteomics 4, 3717 (2004).

110. G. Wu, R. H. Datar, K. M. Hansen, T. Thundat, R. J. Cote and A. Majumdar, Nat. Biotechnol. 19, 856 (2001).

111. F. S. Ligler, C. R. Taitt, L. C. Shriver-Lake, K. E. Sapsford, Y. Shubin and J. P. Golden, Anal. Bioanal. Chem. 377, 469 (2003). 